gitis the skin was non-reactive to an intradermal test with 1:100 old tuberculin (O.T.). Cryptococcal meningitis may complicate sarcoidosis..$^{510} \mathrm{Here}$, as in tuberculosis meningitis, proof depends on identifying the causal agent in the C.S.F. and is usually not difficult if the pathologist is alerted to the possibility.

Decisions about treatment are of course easy if a causal agent has been found, but are difficult when the range of possibilities still includes meningeal sarcoidosis, tuberculous meningitis, and cryptococcal meningitis. If there is thought to be a real possibility of tuberculous meningitis, a treatable condition in which the results for both mortality and residual morbidity are better the earlier treatment is started, initiation of treatment should not await proof of diagnosis.

The question of the relationship between the sarcoidosis and the mycobacterial infection when there is evidence of both must be left open. A clinician who defines sarcoidosis as a disease of unknown aetiology, ${ }^{11}$ for the diagnosis of which mycobacterial and fungal infections must be excluded, ${ }^{12}$ can only believe that the mycobacterial infection is coincidental with and not causally related to the sarcoidosis. But one who adopts a definition based on histopathology, without reference to aetiology, ${ }^{13}$ can consider also the possibility that mycobacterial infection may be a factor in the causation of at least some cases of sarcoidosis.

1 Boeck, C., Archiv für Dermatologie and Syphilologie, Wien, 1905, 73, 301. 2 Schaumann, J., British fournal of Dermatology and Syphilis, 1924, 36, 515. 3 Scadding, J. G., British Medical fournal, 1960, 2, 1617.

4 Haroutunian, L. M., et al., Bulletin of the fohns Hopkins Hospital, 1964, $115,1$.

5 Scadding, J. G., Sarcoidosis. London, Eyre and Spottiswoode, 1967.

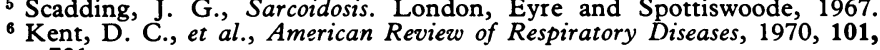

7 Hopkins, A., Fournal of Neurology, Neurosurgery, and Psychiatry, 1974, $37,644$.

${ }^{8}$ Gaines, J. D., et al., Archives of Internal Medicine, 1970, 125, 333.

9 Illingworth, R. S., Lancet, 1956, 2, 646.

10 Clinicopathological Ccnference, British Medical fournal, 1969, 4, 729.

11 Ricker, W., and Clark, M., American Fournal of Clinical Pathology, 1949, $19,725$.

12 Proceedings of International Conference on Sarcoidosis, 1960, American Review of Respiratory Diseases, 1961, 84, 171.s.

13 Scadding, J. G., Postgraduate Medical fournal, 1970, 46, 465.

\section{Oxygen and Radiotherapy}

One of the surprises of radiobiology is the oxygen effect. Surely a cell already suffering from oxygen lack must succumb more easily to the damaging effects of radiation? Not so. The truth is the exact opposite. As long ago as 1909 it was found ${ }^{1}$ that ischaemia (produced by local pressure) helped human skin to resist $x$-rays. Many workers since Gray ${ }^{2}$ have confirmed that a poorly oxygenated cell, whether normal or malignant, can survive a dose of $x$-rays nearly three times as great as that which kills its healthy, well-oxygenated fellow. Many tumours contain viable hypoxic cells. Does their lack of oxygen enable them to survive after otherwise lethal radiotherapy ? ${ }^{3}$ Can oxygen be got to them in sufficient quantity to restore their radiosensitivity ? $^{6}$ Extra oxygen reaching already well-oxygenated cells makes little difference to radiosensitivity, so surrounding normal tissue (which often has to be given top dosage by the radiotherapist for the same reason that the cancer surgeon excises widely) ought not to be seriously affected, except in special cases such as cartilage.?

It is now nearly 20 years since these concepts were put to clinical use ${ }^{8}$ and claimed to be a considerable advance. ${ }^{7}$ Now we read $^{6}$ that much of the equipment purchased and enthusiastically used in North America five years ago is lying idle. What has gone wrong?

Among radiotherapists there have always been doubters as well as believers. The results of randomized clinical trials ${ }^{1011}$ have been conflicting. Some centres seem to have decided that the evidence of benefit (which must not include ${ }^{612}$ too much added risk of harm to normal tissue; nor an increased incidence $^{12}$ of distant metastases) is insufficient to justify the considerable extra burdens imposed on anxious patients and overworked staff. Each patient must spend half an hour or so in an oxygen tent for a treatment that would normally take only a few minutes. Problems of claustrophobia, ear or sinus pain, oxygen convulsions, and fire risk have all been successfully minimized but not completely eliminated.

Meanwhile there are difficulties in agreeing on protocols for the next round of clinical trials. Until recently, the Medical Research Council and others have thought ${ }^{1014}$ that the place of oxygen in radiotherapy would be best put to the test if, in each randomized trial, all other aspects of dose and technique were identical in the two groups. Now it is being suggested that overall policies should be compared, adjusting other variables in each arm of the trial as seems appropriate. For example, those patients given oxygen might have their total dose of radiation split up ${ }^{6}$ into a few large fractions, while the other group would receive small daily doses over a fairly long period. There is evidence 1215 that hypoxic cells may be gradually reoxygenated during a long course of daily radiotherapy, without the need to give oxygen. Moreover, a look at the various clinical trials that have taken place in recent years gives some support to the idea that a few large fractions are best when oxygen is used but small daily doses when it is not. A preliminary report ${ }^{16}$ from Salt Lake City has claimed better results in the oxygen group when these two policies were compared. In Glasgow and at Mount Vernon Hospital, where small daily treatments (with or without oxygen) were given to patients with advanced carcinoma of the cervix, the advantage to the oxygen group was marginal and failed to reach statistical significance, ${ }^{1017}$ whereas in Cardiff ${ }^{14}$ (another centre cooperating with the Medical Research Council) all patients with head and neck tumours were given ten fractions spread over three weeks and the oxygen group showed significantly better local control at all sites, with some evidence of improved survival. Clearly, these contrasting results can be interpreted in more than one way.

Another suggestion is that those not having oxygen should receive more radiation. This might help to settle the question of whether giving oxygen is just another way of giving a higher dose. But how much higher is higher? How many randomized trials at different dose levels would be needed ?

Giving the patient oxygen is not the only way of dealing with hypoxic tumour cells. Suggestions ${ }^{11}$ include chemical radiosensitizers acting specifically on hypoxic cells; very high or very low doses of radiation per minute; protection of normal cells by chemical means or by making them hypoxic; even the injection of obligatory anaerobic organisms with cytotoxic properties. But the best bet seems to be to use neutrons (or other heavy particles such as protons), which are much less affected by the presence or absence of oxygen. ${ }^{11} 1819$ Further reports from Hammersmith (and from the new neutron teams at Manchester and Glasgow, when the frustrating technical problems of the new deuterium-tritium generators have been ironed out) will be awaited with interest. Meanwhile, the use of oxygen should not be prematurely abandoned. The best way of using it is still not clear; nor which tumours to use it 
on. An oxygen tent costs a lot less than a heavy particle generator. More clinical trials are needed.

1 Schwarz, G., Münchener medizinische Wochenschrift, 1909, 56, 1217.

2 Gray, L H., et al., British fournal of Radiology, 1953, 26, 638.

3 Thomlinson, R. A., and Gray, L. H., British fournal of Cancer, 1955, 9, 539.

4 Van Putten, L. M., and Kallman, R. F., Fournal of the National Cancer Institute, 1968, 40, 441

5 Hewitt, H. B., Chan, D. P. S., and Blake, E. R., International fournal of Radiation Biology and Related Studies in Physics, Chemistry and Medicine, 1967, 12, 535.

6 Johnson, R. J. R., and Walton, R. J., American fournal of Roentgenology, Radium Therapy, and Nuclear Medicine, 1974, 120, 111

7 Churchill-Davidson, I., et al., British fournal of Radiology, 1966, 39, 321.

8 Churchill-Davidson, I., Sanger, C., and Thomlinson, R. H., Lancet, 1955,

1, 1091. Emery, E. W., British fournal of Radiology, 1964, 37, 722.

10 Emery, E. W., British Fournal of Radiology, 1964, 37, 722. Halnan, p. 309. London, Churchill Livingstone, 1972.

Halnan, p. 309. London, Churchill Livingstone,
1 Duncan, W., British Medical Bulletin, 1973, 29, 33.

12 Wildermuth, O., Radiologic Clinics of North America, 1969, 7, 345.

3 Van Den Brenk, H. A. S., Richter, W., and Hurley, R. H., British fournal of Radiology, 1968, 41, 205.

14 Henk, J. M., ot al., Clinical Radiology, 1970, 21, 223.

5 Alper, T. L., in Modern Trends in Radiotherapy, ed. T. J. Dealey and C. A. P. Wood, p. 1. London, Butterworths, 1967. 16 Plenk, H. P., American Fournal of Roentgenology, Radium Therapy, and

17 Dische, S., British fournal of Radiology, 1974, 47, 99.

18 Catterall, M., and Vonderg, D. B., British Medical fournal, 1974, 3, 137.

18 Catterall, M., and Vonderg, D. B., British Medical fournal, 1974, 3, 137.
19 Catterall, M., Hutton, I., and Burn, I., Proceedings of the Royal Society of Medinine, 1974, 67, 656.

\section{A Rose by Any Other Name}

Primary medical care-at one time seen by cynics as no more than general practice given a fancy name-is now beginning to acquire a clear identity, and one which is proving attractive to new medical graduates. ${ }^{1}$ The fundamental differences between primary care and traditional general practice are its use of a team of health professionals rather than the solitary figure of the family doctor and, as episodes of acute illness have become less prominent in domiciliary medicine, the priority given to prevention and supportive care.

It would, therefore, be wrong to see the primary health team simply as a means of stretching medical care by providing family doctors with a corps of ancillary workers. Its purpose is to enlarge the scope of primary care, so that it provides a more comprehensive health service rather than just a means of treating illness. This emerges very clearly from Primary Health Care Teams, ${ }^{2}$ a report published last week by the B.M.A. Board of Science and Education, which discusses the provision of health care in developed and developing countries. In Britain at least Professor A. D. Roy and his fellow-experts made two assumptions: that a general practitioner should be at the centre of the health team and that the trend will continue for general practitioners to form large groups and to work from health centres. Once large teams have been set up, they saw the emphasis as likely to continue to move towards preventive programmes-including both health education and screening for early disease-and towards rehabilitation and special clinics for the chronic diseases.

Formation of these primary health teams will have an effect on the shape of the hospital services, too, says the report. It recommends development of community hospitals, staffed by members of the primary health teams but able to call upon consultants for advice. Somewhat provocatively, perhaps, the report argues that the provision of general practitioner maternity units within community hospitals "would accelerate the disappearance of domiciliary midwifery, whereas a trend towards the district general hospital would be likely to result in women choosing to be delivered at home rather than make long or complex journeys to be confined." Another thoughtprovoking conclusion drawn by the panel is its suggestion that the comprehensive care provided by the primary care team should reduce demands on hospital accident and emergency departments, and should also make it possible to dispense with deputizing services.

Clearly if the amount of clinical work done by the primary team is to increase in this way and there is to be no great change in the number of doctors then some of the work done by doctors at present will have to be done by someone else. The future role of nurses in primary care is still far from agreed -and indeed the panel members took different views on the matter. No-one disputes that nurses' work should be tailored to their skills-and that means not wasting the time of a modern S.R.N. making beds. But should community nurses concentrate on their traditional role (in primary care) of preventive medicine or should it be enlarged to include curative medicine too? The panel suggests that it is practicable for nurses to assess patients and initiate therapy-though "only under the effective supervision of a medical practitioner and only in specialized and restricted areas in which they have acquired the appropriate knowledge and skill." One example of such an area within general practice might be family planning, as suggested by Dr. M. Smith and others in a letter this week (p. 161). A wider role for nurses is in line with the proposals made in the Briggs report ${ }^{3}$ for family nursing sisters trained in either clinical or preventive nursing in the community. Professor Roy and his colleagues acknowledge that there is a body of opinion which does not favour any recognition of nurses as competent to make independent decisions: they suggest that the conflict of views could be resolved by a controlled comparison of primary health care teams including nurses with others which did not.

Before rushing to make such comparisons, however, it would be well to remember that the quality of care provided for patients is influenced by other members of the primary care team-social workers, physiotherapists, pharmacists, dietitians, and drivers-and the staff who so often make the first contact, the receptionists. Professor Roy's report states that receptionists "should not be asked to make a clinical decision"-yet very often such decisions are implicit in arranging appointments. One of the main criticisms of current trends in general practice discussed in the Godber Report ${ }^{4}$ was the barrier that receptionists could erect between patients and their doctors. Sometimes health centres and large groups may seem more of a success to those working in them than to the communities they serve. In an era when consumers' voices are so influential, they should not be left out when traditional patterns of behaviour are abandoned, no matter how good the reasons.

\footnotetext{
1 British Medical fournal, 1974, 4, 50.

2 B.M.A. Board of Science and Education, Primary Health Care Teums, (Professor A. D. Roy, chairman). London, B.M.A., 1974.

${ }^{3}$ Report of the Committee on Nuring (Professor A. Briggs, chairman). London, H.M.S.O., 1972 .

4 General Medical Services, Report of the Joint Working Party (Sir George Godber, chairman). London, H.M.S.O., 1974.
} 